\title{
Japan debates plutonium
}

\section{Tokyo}

WHAT should Japan do with a vast pile of weapons-grade plutonium that the Japanese nuclear power industry will have on its hands by early next century? After two years of debate, a subcommittee of the Atomic Energy Commission is expected to recommend soon that most of the plutonium enough to make thousands of nuclear weapons - should be used in conventional nuclear power plants until commercial breeder reactors, which are designed to use plutonium, come into operation sometime in the distant future. Critics say, however, that this is a very uneconomic solution and that instead Japan should completely revise its nuclear policy to eliminate production and accumulation of the highly toxic and dangerous material.

The plutonium - derived from reprocessing of spent Japanese nuclear fuel - will be brought back into Japan from reprocessing plants in France and the United Kingdom beginning next year. The imports themselves have been a matter of international controversy because of possible accidents or hijack during transit, and Japan has had to build a special armed vessel for the purpose.

In addition, a new commercial reprocessing plant that is being constructed in the north of Japan will also supply the industry with plutonium beginning in 1998 .

Severe delays in development of commercial breeder reactors have left Japan with the problem of putting the plutonium to practical use. When the Japanese nuclear power industry signed contracts many years ago with the United Kingdom and France to reprocess nuclear fuel, Japan was planning to use the plutonium in commercial breeder reactors by 2010 . But technical difficulties in development of breeder reactors and the plentiful supply of cheap uranium for con- ventional reactors have pushed back the starting date for commercial breeder reactors to sometime between 2020 and 2030 . And there are doubts that even this schedule will be met.

Atomic Energy Commission officials estimate that Japan's inventory of plutonium will balloon to 84 tons by 2010 , compared with only a few tons at present, according to a report from the Kyodo wire service last week. The commission's nuclear fuel subcommittee is expected to recommend that most of the plutonium be used in twelve conventional light water reactors by mixing it with ordinary uranium fuel.

Kimikazu Iwase, deputy director of the nuclear fuel division of the Science and Technology Agency, says that the Kyodo figures are not the official ones that will be released in the next few weeks. The subcommittee's final figures may be "slightly different", he says. But the conclusion that the plutonium should be used in conventional reactors is in line with the commission's 1987 long-term policy, he adds.

Paul Leventhal, president of the Washington-based Nuclear Control Institute, an organization that monitors proliferation of nuclear weapons, questions Japan's whole policy. "Using plutonium to fuel ordinary light-water reactors is inefficient and dangerous," he says. "The introduction of plutonium-uranium fuel is just a stop-gap measure to avoid an enormous plutonium surplus. The best way for Japan to avoid this worrisome surplus is not to create it in the first place." Leventhal recommends instead that Japan's nuclear power industry renegotiate its reprocessing contracts with France and the United Kingdom to take back lowenriched uranium instead of plutonium.

Iwase admits that plutonium is much more expensive than uranium and thus at present

\section{Monju fast-breeder reactor completed}

FAST-BREEDER reactors may have an uncertain future, but officials of Japan's Science and Technology Agency were all smiles a few weeks ago as they celebrated completion of construction of Monju, Japan's first prototype fastbreeder reactor.

Located on the Japan Sea coast, Monju represents one of the biggest investments ever made by the Japanese government in a research and development project Six hundred thousand million yen ( $\$ 4,300$ million) has been sunk in Monju. Construction of the plant, which took nearly six years, required a workforce of more than 2,600 and involved four major equipment manufacturers (Toshiba, Hitachi, Fuji Electric and Mitsubishi Heavy Industries) and nine construction companies.

Monju has a loop-type primary and secondary cooling system filled with liquid sodium. The sodium provides very efficient heat transfer to the steam generator, but it is an extremely dangerous material which catches fire spontaneously in air or in the presence of water, and much of the cost of construction has gone into making the sodium cooling system leak-proof. The reactor has also to withstand major earthquakes.

The prototype fast-breeder reactor, which will have an electrical output of $280 \mathrm{MW}$, is scheduled to reach criticality in October next year, and Japan plans to begin imports of plutonium from Europe at that time to fuel the reactor. The next step will be for the electric power industry to build an even bigger demonstration fast-breeder reactor. But details of that project are not yet known, and Japan is not expected to have commercial breeder reactors in operation until at least 2020-30. is not a very economic fuel for conventional nuclear reactors. But he argues that in the long term as Japan uses more and more plutonium, the price will drop.

Price, however, is not Japan's main concern. Government officials and the electric power companies are determined to establish a complete nuclear fuel cycle in Japan, including the production of plutonium from spent nuclear fuel, so that the nation will be less dependent on fossil-fuel imports. The government and industry have already invested thousands of millions of dollars in this policy, and it seems they are determined to forge ahead no matter what the cost.

David Swinbanks

\section{ARMS CONTROL \\ South Africa to sign}

London

AFTER years of suspicion that South Africa was developing nuclear weapons, its government last week ended the speculation by both admitting that it had the capability to produce such weapons and at the same time promising never to use them. In agreeing to sign the 1970 Nuclear Non-Proliferation treaty, President de Klerk said that South Africa would open all its nuclear facilities to outside inspectors and move towards establishing the country as a nuclear-free zone. The treaty essentially promises that the signatories will neither acquire nuclear weapons if they do not have them, nor help non-nuclear nations gain nuclear capability. In the aftermath of the Cold War and the reduction in superpower tensions, several previously recalcitrant countries - including France last month - have agreed to sign the treaty. Of the nations that had nuclear capability when the treaty was established, only China is yet to sign.

NUCLEAR POWER

\section{Bulgaria's dilemma}

IN an unusually strong statement, the International Atomic Energy Agency (IAEA) has urged the Bulgarian government to shut down its nuclear power plants in order to avoid a catastrophic accident.

The Vienna-based United Nations agency warned the Bulgarian government last month that its plants were not safe and that they should be shut down immediately, an agency spokesman said. Bulgaria responded by shutting down two of the four plants located at Kosloduj on the Danube River, but it continues to operate two other plants because it said it could not afford to give up the power they provide. All four are 440-MW plants of the type WWER-440 built by the Soviet Union.

Concerned Western officials, led by German environment minister Klaus Töpfer, have agreed to meet at IAEA headquarters in Vienna next week to discuss providing alternative sources of energy to Bulgaria.

S.D. 